\title{
Who's Who in the Zoo: Tonga Election 2014
}

\begin{abstract}
This paper reflects on fieldwork Teena Brown Pulu and Richard Pamatatau conducted in Tonga on the people's election and the nobles' election of November 27th 2014. Who's who in the zoo? ${ }^{1}$ Ethnographically speaking we mean what did voters say of the leadership and government needed, and the country's priorities for moving forward? Furthermore, how was Tongan "life, liberty and security" made sense of? (United Nations, 1948). With Democratic Party leader 'Akilisi Pohiva elected prime minister for the 2014 to 2018 term of government, what was different now?

Written by Teena Brown Pulu with Richard Pamatatau's fieldwork notes woven in the text, the essay probes two critical interstices. Why do ethnic Tongans insist the authors can critique Tongan politics and society in ways they cannot for risk they will be rebuked by established canons exerting authority and control over citizens? Who then in Tonga can disrupt the taken for granted categories of class, culture, and politics, and who cannot?
\end{abstract}

Teena Brown Pulu is an anthropologist and senior lecturer in Pacific development in the Faculty of Maori and Indigenous Development at Auckland University of Technology.

Richard Pamatatau is a journalist and programme leader of the graduate diploma in Pacific journalism in the School of Communication Studies at Auckland University of Technology. 


\section{Sorry, we're British half-casts}

I begin with a tale of Tongan sense explained to me by an insider. Political scientist Malakai Koloamatangi once cautioned that if well-known broadcaster Sefita Hao'uli speaks up to directly address you, pay attention, because more than likely you are in big trouble. As a hybrid woman born, educated, and employed in New Zealand of Tongan and other ancestries, a reputed smart aleck who has been scolded by Sefita for having a ding-dong go at people I personally loathe and would like to see transferred to another planet in the solar system, Malakai's depiction fits the bill.

At a generalising level, Tongans do not consider it culturally correct behaviour to publicly bollock people one strongly dislikes in a confrontational manner spoiling for a fight. In my circumstance, cross-cultural contamination is blamed as the reason why I am incapable of conforming to the norms of public life which Tongans are bogged down with, and over-burdened to perform. Half-casts reproduced by a handful of colonial European traders who settled in Tonga and married Native women, particularly the British stock over their German counterpart, are exempt from observing some (not all) protocols forced on full-blooded Tongan commoners. This idea, the essay teases out.

I do this for two mutually related reasons. In Tonga halfcast is a categorization I personally put on and act out because it provides a public escape route from identity sentencing as a Tongan commoner in everyday life. Who in this 21 st century day and age seriously wants to be labelled a commoner by an outdated establishment of royalty and nobility? Get in the real world, Tonga. As I have audaciously exclaimed in a paper that contributed to a co-presentation with my colleague Richard Pamatatau at the Human Rights in the Pacific conference hosted by Massey University, Albany, “Be jealous of me too. I ain't royal and I ain't no goddam commoner with ebola" (Reading the Maps, 2014). 


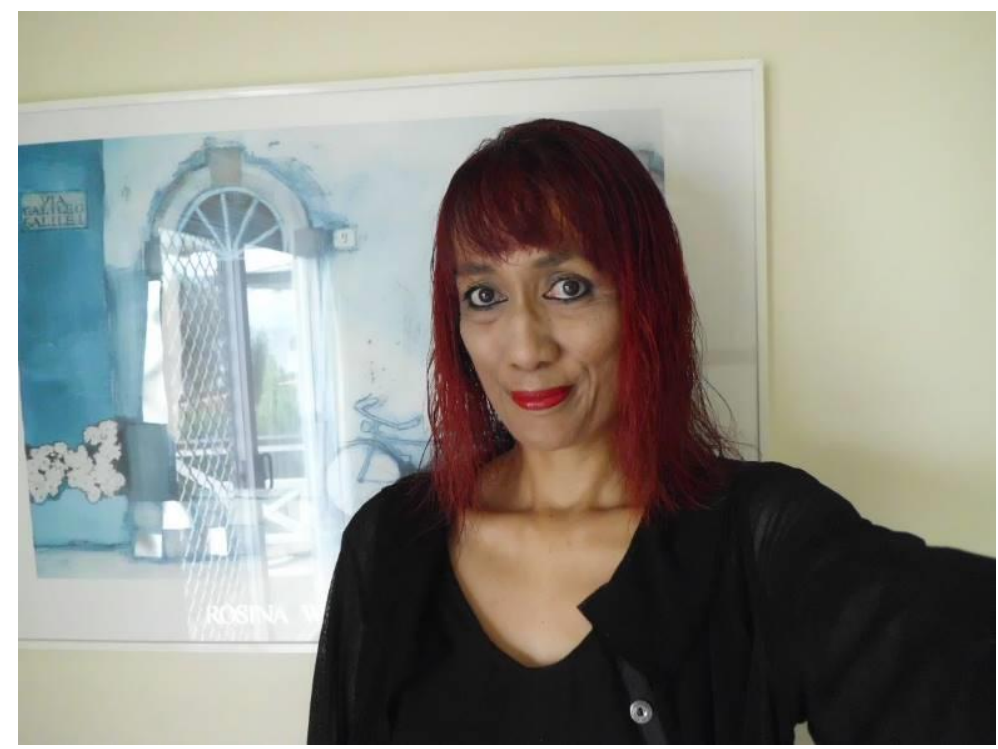

Photograph 1: Teena Brown Pulu in Tonga researching the election 2014.

Richard Wolfgramm, a German and Tongan hybrid born in the Vava'u group of Tonga who migrated to Salt Lake City, Utah in the United States where he works as a graphic designer, put it aptly.

Kainanga 'oe Fonua = eater of dirt/soil = commoner in Tongan. Me'avale is another term, [it] means "the stupid ones or stupid things." Don't you just love these Tongan aristocratic/noble class terms of endearment? (Wolfgramm, 2015).

Wolfgramm was penning sarcasm. The correct answer was NO! stressed in capital letters with a loud exclamation mark. By this, no person whom I know of Tongan ancestry and who is not of the royal household or the nobility loves, likes, or finds it in any way palatable to be slurred a dirt eater. Beyond offensive, it is an obnoxious reminder to people labelled 
commoners of what they loathe about a class system - a depraved sense of superiority and entitlement afforded the upper stratum of society. Festering below was the rancid root that continued to sever, not unite, Tongan society.

Secondly, although half-cast denotes a limitation on personhood in Tonga, its engraftment on Richard and I affords us intellectual freedom to do something Tongan commoners are not meant to according to social custom. That is, to speak up publicly and directly to the powerful about their role and responsibility in perpetuating structural inequalities which deepen, rather than diminish, the predicament of poor people at the hierarchy's bottom.

Richard's Native ancestry is not traced to the Tonga Islands but rather, the Cook Islands or specifically Mauke, an atoll in the Cook's southern archipelago which is a forty-five minute flight on a 12-seater domestic airline from the main island of Rarotonga. Mauke is where his mother was born and spent her childhood living in a family homestead still standing today. Similar to others born in islands making up sovereign nations of the Pacific region, Richard's mother passes on to him her Native identification code couched in a network of connectedness to Mauke.

For me it is simple - my mother was born on Mauke, one of the three islands that make Nga Putoru in the southern Cook Islands, and that makes me by birth, heritage, DNA and history, a Pacific Islander. One branch of her family has lived there for hundreds, possibly thousands of years and many tupuna or ancestors are buried in a cemetery in the centre of the island. And, for the purposes of this essay, highlighting the Pacific aspect of my heritage at Radio New Zealand ignores my British, German and Australian-via New Zealand ancestry. At no stage has a colleague said: "You don't look or sound German." 
No one ever asked me for sauerkraut or bratwurst.

(Pamatatau, 2012, p. 187).

As a colleague and for the purpose of this paper, a fellow researcher branded as half-cast in the South Pacific, I have found a persistent muddle people often get themselves in is misspelling Richard Pamatatau's surname, ${ }^{2}$ or somewhat worse than that, not altogether realising he has Native Pacific Islander ancestry until he tells them. I say worse than making a hash of correctly spelling his family name because the uncomfortable looks on white people's faces when Richard explains he is a Pacific person is troublingly amusing in this age of hybridity and in-between identities.

What do they see? Illuminating this query is Radhika Mohanram's probing of how the Native is identified and deidentified in what are considered "un-natural environments" such as cities not islands, and universities not villages. "In terms of locale, the metropolis functions as the binary opposite to the 'natural' environment. But does one stop becoming a native in 'un-natural' environments?" (Mohanram, 1999, p. 9).

The reality of day-to-day life for Richard and myself is that our workplace in a metropolitan university of New Zealand, a developed country of the Pacific rim is inscribed "as the binary opposite to the 'natural' environment" of Native Pacific Islanders (Mohanram, 1999, p. 9). Richard, more than I, therefore becomes subjugated by a process of de-identification as a Native because of racial phenotype in that his skin tone is lighter than mine. He gets mistaken as solely a white European male minus the Native ancestry by white people who wrongly assume his complexion automatically makes him the same as them. 


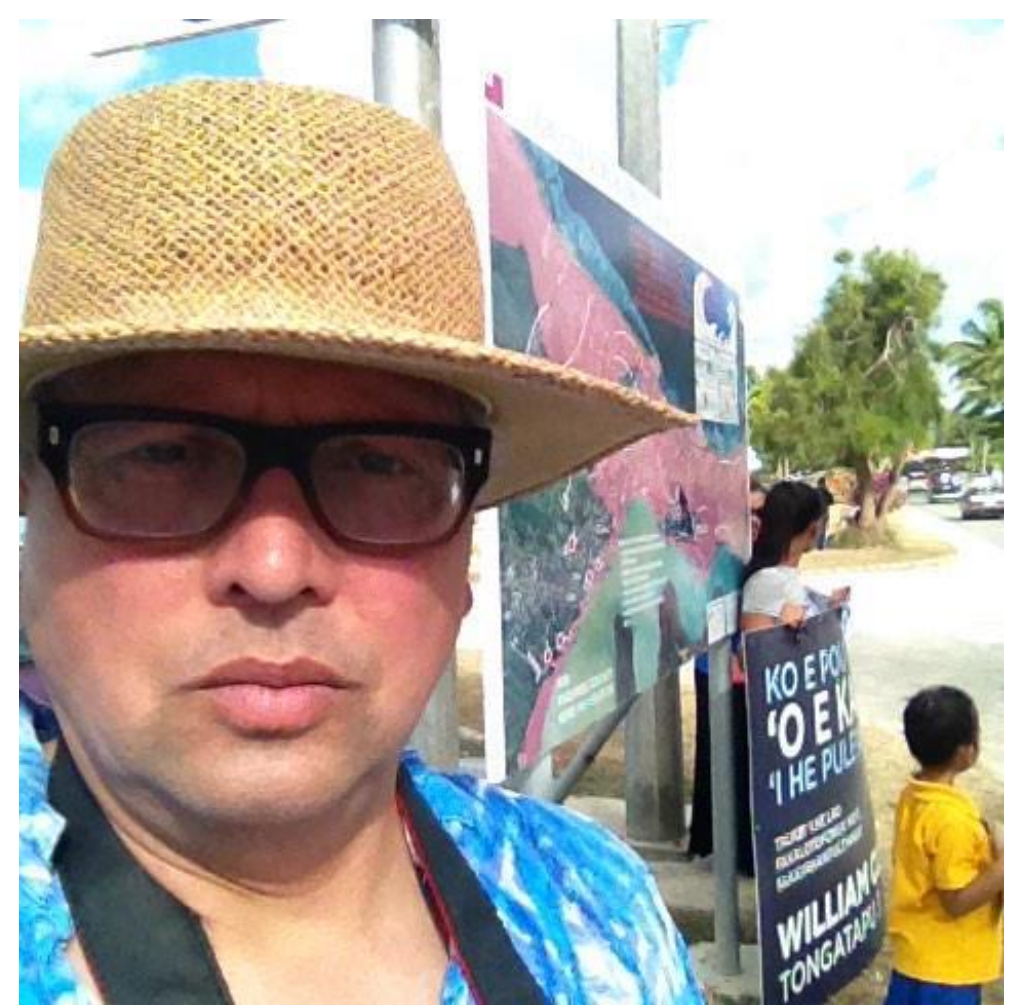

Photograph 2: Richard Pamatatau working the field for the Tonga election 2014.

Being located in Tonga and having to work as field researchers poses a different set of identity conditions to New Zealand. Immediately we are both identified as part European and part Native; two parts racially distinct in skin-colour light and dark - which construct a separate categorisation to full-blooded Natives of half-cast, a social referent traced to the colonial era of late 19th century and early 20th century British imperialism in the Pacific region. An internal hierarchy of racial mixing systematises the half-cast category. The British half-casts are set-up as superior to the German hybrids because of Tonga's historical connection to, and obsession 
with mimicking, British empire as a South Pacific kingdom with a constitutional monarchy.

The truth is Richard can be considered more of a German half-cast than a British half-cast. He displays his European roots and loyalty in work spaces. A flag of Germany hangs on his office door at Auckland University of Technology. But according to Tonga's half-cast hierarchy, my human biology is supposedly superior to Richard because my British (English and Scottish) genes not compromised or tainted by German ones.

However, Richard passes for a superior half-cast of British and Native ancestries. Despite coming across as a German hybrid due to his forthright and fearless communication style of challenging white people's authority over Native Pacific Islanders in public forums where the majority present are white people, his lighter skin colour and New Zealand citizenship and socialisation prop him up in good stead to Natives gazing at the half-cast performance. Convincingly he passes the identity audition on stage.

In Tonga, passing the test is all the Native audience is fixed on. Often they are fooled by political actors who might not qualify but can survive their assessment. Two discrete types of background checks construct the half-cast predicament of culture (Clifford, 1988). First, a person's European and Native genealogy has to stack up as legitimate. In my case, I have a half European and half Native mother born in Tonga in 1946. At birth, paternity afforded her British citizenship by the authority of the British High Commission's head office in Port Moresby, Papua New Guinea. This gives me genetic half-cast authenticity, a passport of lineage to escape, evade, and elude the social and financial demands of what is taken as traditional culture, class boundaries, and gift-giving enforced on full-blooded Natives.

Second, a person who wears the identity category is socially expected to perform the everyday content of half-cast with credibility. This is where impostors and cons can make 
villainous appearances on stage and be called out as antiheroes. There are definite ways and means of verifying halfcast identity among this class group, and passing as a real one can be soaked in discrimination and judgement.

To spin this phenomenon in a story, when my mother's eldest sister Aunt Nina (nee Brown) Avery was alive and living in our family homestead in Haveluloto village, Tongatapu, she was a member of the ladies' bridge club. She would take turns at hosting bridge with club members who were half-cast women, or Native Tongan women married to high society men such as nobles, judges, lawyers, doctors, or businessmen.

One bridge club member affiliated to a half-cast German family from Vava'u, the northern outer-islands of Tonga. She had married a noble; to be precise, the nobleman who was close kinfolk to us, the Brown's, through my maternal grandmother 'Ana Kaho, a Native Tongan woman. My aunt and her associates of half-cast British ancestry found her to be fake, spurious, and bogus. It was not singly German hybridity that failed her, but rather, her father was an illegitimate grandson of a German trader. By social ideals, illegitimacy cancelled out her bloodline for half-cast entitlement. Added to this, not passing the perfomative identity test confirmed her elimination from the restricted pool of genuine half-casts (Butler, 1990).

This woman did not speak with a pronounced English speaker's brogue. Her English was clumsily enunciated like a Native spitting out Donga with a D not Tonga with a T. Plainly she sounded wrong to English speaking ears. Furthermore, she had not been sent offshore to New Zealand for boarding school education at secondary level. Her incompetency at performing private school manners and politeness showed. Murmured among the bridge ladies was that she came from an ordinary Tongan family of modest means. Pitiable thing. How disadvantaged not to have the right background and breeding. The true class station of a person would always show up when closed circles tested for validity. 
Various Native classes operating in Tonga, whether they be upper, middle, lower, or half-cast intersect in laying down guidelines and tests that determine the real ones from the phonies. Social groups harbour their own internal politics in which acts of passing for one of them and performing identity are normal. It is therefore taken for granted that this is how the Natives, including half-casts, behave when playing out culture, class, and race categories. Who goes out of their way to trouble categories? (Butler, 1990). What I mean is in Tonga, how do people destabilise social boxes by performing identities that go against the grain, or by evading and eluding the confines of only being this and not that?

The election of 'Akilisi Pohiva to Tonga's premier compounded by Western media in New Zealand deifying his persona to the godlike status of symbolising everything to do with Tongan democracy, subverts identity categories. Pohiva represents an odd premier on niggling counts. His core supporters were the poor underclass, but this did not mean his Democratic Party gained the majority of the popular vote nationwide. ${ }^{3}$ He fudged overseas and local media by not giving a clear indication of what government policy priorities were for the four-years ahead in office (Moala, 2015). ${ }^{4}$ Instead, he avowed that "the [Democratic] Party has our own Code of Conduct and we will use that as a guide for the Cabinet Ministers and Parliamentarians" (Tora, 2015).

Ministers of the Pohiva administration along with parliamentarians attended a "special church service at the Sopu Free Wesleyan Church" on the first working day of government, Monday the 5th of January 2015 (Tora, 2015). This was Pohiva's church, and the religious purpose was for Tonga's prime minister to receive a protestant blessing from a Wesleyan minister. The identity performance conflicted with Western perceptions that Pohiva was the spreader of liberal democracy and the secular state in the Christian Kingdom of Tonga. 
Unravelling in public life was the telling truth that he possessed and practiced conservative values oriented in 19th century protestant Christianity, which were compatible with King Tupou VI's stand that "the boundaries [between government and monarch] were clearly defined and would not be overstepped" (Latu, 2015). Put simply, in an inaugural meeting between Tonga's incoming Prime Minister Pohiva and King Tupou VI, the monarch gave clear direction on how the country would run. The national executive of cabinet was not to intrude on his rights and privileges as the constitutional monarch who sanctions Tongan law, who is the undeniable head of state, and who is the commander in chief of His Majesty's armed forces capable of enforcing martial law (Latu, 2015). End of sermon on the mount (Latu, 2014b). 5

The cultural truth was Western media and academia replete with a self-opinionated horde of experts were prodigiously ignorant about the intricacies and details of how Tongan politics play out and why it ends up the way it does. In Tonga, multiple political actors perform live stories rupturing culture, class, and race categories, severing their permanency, and exposing the majority's flawed and unquestioning acceptance of power and authority. In fact, the most unlikely characters act out in the most unlikely ways.

I mean to say, for the stage production of the Tonga election 2014 and the instatement of 'Akilisi Pohiva as Tonga's prime minister, the one noble actor appointed to cabinet was a stellar performance. Why was Lord Ma'afu's ministerial post inside the Pohiva regime misread as a constitutional requirement in that it was believed a noble had to assume the lands portfolio? (Latu, 2014a). Why did overseas media, including Tongan bloggers and observers in New Zealand, not see Ma'afu as a critical intermediary between class groups in power?

On the overseas front of Tongans in New Zealand, Sefita Hao'uli, prominent broadcaster and political commentator on Tonga's affairs put up an unusual opinion for public debate. 
He saw the opposition to the Pohiva government was not in the House, but came down to "we, the people" (Akel, 2015). Without an effective opposition, democracy ceased to function thought Sefita (Akel, 2015).

There were other Tongan personalities considered real McCoy Natives, who although were too numerous for this paper's noting, actively contravened conformist categories of culture, class, and race. By stepping around, outside, and through the political rhetoric that nobles are like this, and commoners are like that, they staged a South Seas drama about pineapples and coconuts not being classified as the same kind, but none-the-less growing in the same climate and country.

In actuality, the oddity was Western media and academia. People employed in these work industries were incapable of moving beyond the binary mindset that nobles and people's representatives in parliament were arch enemies. It was not singly white reporters and researchers that grasped this line, but Tongans living overseas who were indoctrinated by their Western countries of residence. No matter how much political life demonstrated the old fighting foes had reinvented themselves and negotiated some of their customary differences, New Zealand critics hung on to dated narratives of class wars.

This is an essay where I have pieced together Richard's field research notes and my critical analysis, along with entries from journals we have kept as university collaborators working and writing the field for the Tonga election of 2014 and its after-effect. The paper travels an unconventional route in academic structure and style. In a matter of fact tone, we are original, quirky, and experimental academics in our respective disciplines of journalism and anthropology of the South Pacific region, and generally for area studies on contemporary theory about countries and cultures in change.

Woven in between me reading who's who in the zoo by contextualising political actors reconfiguring the political 
landscape at the election's advent and aftermath, are Richard's stories from the field. Our co-authored piece is organised this way because talking story is how ideas move from one culture to another (Said, 1991, pp. 226-247). For us as identity wearers of the half-cast category it has been, and always will be, the method by which we have learned that Native storytellers are the experts on the contents of their lives.

\section{Something about Sefita}

To rewind the tape to a Sefita Hao'uli story, he has a matrilineal blood tie to the late Futa Helu who passed away in February of 2010 before Tonga's electoral reform commenced at the November 25th 2010 election. The familial relationship which is traced to Foa, the largest island in Ha'apai, the central group of low-lying atolls in Tonga, speaks volumes in Tongan circles. It explains something of his poised way in hitting the nail on the head when arguing his point, and cleverly timing his entry into public debates to upturn the pineapple cart with an alternative viewpoint.

Being a Foa islander relative of the South Pacific Kingdom's controversial but revered, almost feared intellectual, has distinct advantages inside Tongan society. It yields a Native-styled escape route. Many Tongans see Sefita's offbeat political opinions and boldness in putting it out there as socially acceptable, tracing the identity origins of such outspoken behaviour for a Tongan in the first instance to Futa, his scholarly kinfolk of 'Atenisi Institute who was considered an activist and radical thinker for his generation and time.

In the wider Tongan ethnoscape, Sefita's candour merged with eloquently spoken and written language in Tongan and English is linked to Futa's philosophical manner of communication, which in turn, is framed as a Foa islander characteristic (Appadurai, 1996). My thrust is who you are in 
respect to your village and island origins, and your kith and kin connections, matter to Native compasses when pinpointing your identity, belonging, and location in the Kingdom of Tonga.

It came as no surprise that Sefita was quick off the mark in critiquing the political elbowing going on between the people's representatives to the Tongan parliament. The Democratic Party members and their independent counterparts were jostling for ministerial portfolios in a coalition government for the 2014 to 2018 term. A former broadcaster and journalist by trade he was not tight-chested with his views and frame of questioning in public media.

Addressing Matangi Tonga about an online publication, People's Reps call for a commoner Prime Minister, his voice turned an internet news item into a conversation prompt where other Tongans felt compelled to write in with their opinions. Thus, Sefita spoke candidly about the shortcomings of plying for political self-interest (Matangi Tonga, 2014).

The sentiments for a commoner Prime Minister is touching but will soon be forgotten if we end up with someone who is unable to appoint and lead a Cabinet of our most able talents. It isn't enough that the two "parties" signal a leader preference at separate meetings behind closed doors. They could at least come together in one room and hammer out a collective effort not just to form a government but to seed and provide adequate resources for an effective opposition. The country is being denied the benefits of our new democracy because once again, our focus has been on who will wield power rather than how best power can be shared for the benefit of all. It appears that we have not learned anything from the last four years. (Hao'uli, 2014). 
The accuracy of Sefita's foresight was uncanny. He had adjusted the analytical lens with precision, inspecting the political conditions under which a coalition government would be formed, and had to hold together and function stably over a four year period. The shortened version of a longwinded tale is that the deal went down something like this. In exchange for a box tick alongside Akilisi Pohiva's name at the prime minister's election on Monday morning of December 29th 2014, five independent people's representatives got ministerial portfolios in a coalition government headed by Pohiva. In brief, Akilisi Pohiva defeated his opponent Samiu Vaipulu by 15 votes to 11 at the premier's parliamentary election, and the list of cabinet ministers was accepted by King Tupou VI and announced by the Government of Tonga on December 31st 2014 (Government of Tonga, 2014).

Was this taken as a fair trade off at the bargaining table by Tongan voters in the November 27th 2014 general election who had waited over a month to usher in a new premier and cabinet for the 2014 to 2018 term? Only time will tell; however, there was support as well as grumbling about the concessions the Democratic Party made by transacting ministers' jobs for premier's votes at the talk table. A biting criticism turned up in public opinion. Given Akilisi Pohiva was known for preaching on about political morals, was it principled to promise cabinet seats and salaries to five independent people's representatives to secure the top job as Tonga's prime minister? Who really benefitted from compromise politics, the head of government or the ordinary Tongan voter?

Immediately after Pohiva was elected prime minister, surplus media accounts emerged. Deductions proliferated on what direction his government would travel by implementing policies and further reforms to Tonga's parliamentary structure to finish building a liberal democracy the West, namely New Zealand, Australia, and the United States, were satisfied with (Akel, 2015; Fonua, 2015; Latu, 2015a, 2015b; 
Locke, 2015; Matangi Tonga, 2015; Moala, 2015; New Zealand Herald, 2015; Tora, 2015). Put simply, this meant gratifying the West by creating Tonga in its image and likeness by having a Tongan parliament that abolished the nine nobles' representative seats, and was exclusively for people's representatives elected by registered voters on the general roll.

Prior to Pohiva's instatement as premier, the Democratic Party of the Friendly Islands which he led only released one party brief for public dissemination on September 15th 2015, outlining their political objectives if they formed the majority in government (Latu, 2014c). Little information about official party strategies was circulated to a wide range of news outlets, affirming what the national plan of a prospective Pohiva government would resemble. Media stories, as opposed to rigorous political analyses, expectedly overflowed to fill up the public knowledge gap (Fonua, 2014; Hill, 2013, 2014a; Kaniva Pacific, 2014; Latu, 2014a, 2014b, 2014c; Matangi Tonga, 2014; Moala, 2014a, 2014b; Radio New Zealand, a-i; Tora, 2014; Vaka'uta, 2014; Wiseman, 2014a, 2014b).

After assuming office, however, it became evident that Pohiva had rerouted to his original stance of weeding out what he believed was the Tongan state bureaucracy's age-old affair with corruption. Repeatedly he used the popular language of "good governance," urging that unyielding "checks and balances" in the state machinery provided "the key to development," and that no "economic policies" could be moved until the state was free of immorality (Radio New Zealand, 2014a).

The following three media excerpts are quoted from New Zealand and Tongan media. Read together as a record of key messages Pohiva deliberately put out in the public domain after taking up Tonga's top job, two correlated points can be considered by media and academic researchers when contextualising what it is, precisely, Prime Minister Akilisi Pohiva has set out to do in four years of government. First and foremost, he is convinced that "good governance" in Tonga 
amounts to the increased bureaucratisation of the public service, to the point where, "appropriate checks and balance mechanisms" will throttle the living daylights out of corrupt practices and depraved behaviour (Radio New Zealand, 2014a).

Second, and related to the first point, his baseline objective is for his cabinet ministers "to take action [on] the fair distribution of national wealth," which they will according to Pohiva, largely because of their superior "high moral principals" compared to former administrations governing modern Tonga since the inauguration of the 1875 constitution (Fonua, 2015). What I am alluding to is Tonga's current prime minister mixes conservative Protestant Christian values originating from 19th century Tonga, with his political ideals located in the 1960s and 1970s epoch of independence for South Pacific states. Truly, he cannot be simplistically read as a liberal democrat by Western standards of New Zealand, Australia, and the United States.

What is most important at this stage is to make sure that we have a [sic] good governance. And I think good governance is the key to development. We have to make sure that we have all the checks and balances that are necessary and appropriate checks and balance mechanisms put in place before we can move on. Before we look into economic policies and all that. ('Akilisi Pohiva cited in Radio New Zealand, 2014a).

'Akilisi stressed that while national issues and their solutions had been identified but what had been missing "was the will and the commitment to take action." When asked to identify the priority issues that he and his government had to deal with urgently, he implied that his government has the will to "take action," guided by the high moral principals [sic] of "Good leadership, justice for all 
and the fair distribution of national wealth." ('Akilisi Pohiva cited in Fonua, 2015).

My Cabinet will take action first on matters relating to minimizing the costs of transportation, official travel and any other expenditures that can be reduced or are avoidable. We would be able to measure success when we [see] a cultural change in the civil service [which] had a reputation that is appalling, representing waywardness, [and] lack of moral courage to withstand the pressures and temptations of the calling to public service. (Matangi Tonga, 2015a).

\section{Sefita unedited}

Sefita Hao'uli: A number of things which I brought up in the [Torben] Akel interview [for 3 News at Television New Zealand on 4 January 2015] and which probably ended up on the floor in the editing suite was that the nobles are not necessarily opposed or in opposition to Akilisi, and in fact, it would be in the nobles' better interests if Akilisi was to run an efficient and stable government.

The opposition that is needed for our democracy needs to come from "We, the people" now, because there is no organised political opposition at present. "We, the people" are better mandated than the nobles to point out to government what they are doing wrong. Akilisi and the people's representatives are more likely to respond to challenges from "We, the people" because it is where their power resides and comes from.

[Torben] Akel may not have seen it as important but I pointed out that our women are more likely to move into this vacuum and [I] am seriously hoping that it would be the case. A nationwide village/electorate movement based on the needs of our women will bring a much needed different agenda to parliament and cabinet - and with it, women MPs [members of 
parliament] and cabinet ministers. Here's a bet. That before the end of the Akilisi government, we will see a "We, the people" woman in cabinet and I will welcome it and so will the rest of the country. (Hao'uli, 2015).

\section{Wager on women}

My Pacific ethnic affiliations are from the Cook Islands and Niue, but I don't know every person with a similar heritage and speaking for them is clearly problematic and - from a news reporting point of view - I was never taking a 'Cook Islands' slant. (Pamatatau, 2012, p. 190).

Before tackling Sefita's optimistic wager on Tongan women in parliament and cabinet, I want to unpack Richard Pamatatau's assertion that "from a news reporting point of view I was never taking a 'Cook Islands' slant" (Pamatatau, 2012, p. 190). Couched in a Western university setting where an academic is schooled by a specific discipline to become an expert thinker in, and practitioner of, the discipline, (whether that be anthropology like me or journalism like Richard), his logic rings out truth. "I was never taking a 'Cook Islands' slant," and significantly, why should he be expected to pitch his gathering of information and sense making for public dissemination purely from a Cook Islands angle?

Citing Richard's thoughts earlier in this essay he remarked that "highlighting the Pacific aspect of my heritage at Radio New Zealand ignores my British, German and Australian-via New Zealand ancestry" (Pamatatau, 2012, p. 187). A line of reasoning behind identification as half-cast, hybrid, or mixed blood in Tonga and the South Pacific Islands is that one is seen to have parts in them from other races, and moreover, the other parts are exhibited in that person's speech, thinking, tastes, manner, behaviour, and principles. 
For Richard and for myself, the viral-related gripe that stings and bites about doing research in tropical island countries is the putting aside of fieldwork. There is no hushhush muzzling around the global reality that the internet and social media has transformed how public media, as well as academic research and publishing, is conducted and disseminated. What happens to journalism and academic integrity when Twitter tweets and Facebook posts become the popular pattern used for cutting out and dressing up fashionable news stories, television sound-bites, or scholarly research? How does mass migration to the worldwide web and digital media disturb and distress academic disciplines and professions like ours - journalism and anthropology - founded on doing fieldwork, working the field, being located among the people and in the place the fieldworker is studying, gathering data from, and carrying out research on?

Linked to this is the second intellectual influenza epidemic that belies the dearth and demise of skilfully and systematically executed fieldwork in Tonga and the Pacific Islands region. Academics like Richard and I who claim Native Pacific Islander ancestry are uncritically expected to take "a 'Cook Islands' slant," or write from a Tongan perspective, or collaboratively pitch our fieldwork and publications as Pacific Islanders, or use a New Zealand Pasifika [Pacific] term for research method such as talanoa [types of cultural speech]. (Pamatatau, 2012, p. 190). What do these identity categories amount to in the university research industry which is internationally dominated by the English language as embedded in Western European and American scales of quality and acceptance?

More importantly, why can we not operate in the field as a journalism academic and an anthropologist without lugging around excess cultural baggage to explain for white people's understanding, to validate for Western academia's store of knowledge, the parts of us belonging to Native Pacific Islander peoples and places? Rephrasing American Tongan artist 
Vaimoana Niumeitolu, "We are tired [of having to identify and re-identify ourselves to others when our white university colleagues do not have to in public life], and need a vacation somewhere else" (Niumeitolu, 2010).

Returning to Sefita Hao'uli's wager "that before the end of the Akilisi government, we will see a "We, the people" woman in cabinet," Richard once critiqued in a book chapter how "members of the Pacific population [are] framed as "community leaders" (Pamatatau, 2012, p. 189). Imbedded in lobbying to the Pohiva administration to appoint a female cabinet minister just because there are not any is the value-laden judgement that naturally "the country [should] welcome it" as unequivocally progressive (Hao'uli, 2015).

Those members of the Pacific population who are articulate in English and informed become framed as 'community leaders,' but that leadership does not necessarily play on a broader field. They also become 'go-to' people for a slew of Pacific-related matters whether or not they have expertise in the area. (Pamatatau, 2012, p. 189).

Richard was re-examining the power of New Zealand media to select and make Pacific Islanders "who are articulate in English" their pet "community leaders" whom they "go-to for" publishable comments (Pamatatau, 2012, p. 189). His incisively sharp criticism as a journalism academic can be borrowed to read Tonga's political landscape. Among the Tongan public it is preferred that leaders in high-office whether they are state bureaucrats or politicians communicate proficiently in English. English is the second official language to Tongan, and highly prized as the priority language to have skill and confidence in for getting a job in Tonga, and using this employment status as a stepping stone to migrate overseas for better paid work and a higher standard of living. 
A pending question surfaced. How likely was it, if a female cabinet minister was taken on by Prime Minister Pohiva, that the person would be characterised as "articulate in English and informed," in the sense they are an experienced state bureaucrat familiar with the machinery of government? Subsequently, with all solutions offered on rectifying the fact that women are not present in the Tongan parliament, an awkward assumption was made.

If a woman gets hired for a ministerial portfolio, does her gendered identity as a woman, as a female, naturally qualify her to be the expert on everything and anything to do with women? And would a woman be permitted by the men in power to "play [politics] on a broader field," outside of her assigned identity category as a man's symbolic gesture of all things about women? (Pamatatau, 2012, p. 189).

For myself, as I can only truly speak as myself, I know that if Tongan men in political power offered me a rung on their patriarchal ladder as the token woman, because they had been informed by Tongan women they must get one of those to be gender inclusive, I would frankly tell them to take a running jump. Colloquially this means stop being condescending and go away, for you are annoying me.

I am not saying that women in government is not a crucial signifier of progressive politics in a democratic system of power. However, I am critiquing the method by which increasing women's participation in a system owned and operated by patriarchy, the very system that ironically is meant to save womenfolk from being overruled by men, takes place in the state bureaucracy.

Men consenting to bringing in women cabinet ministers merely to represent other women inflicts paternalism. Professionally, the field of expertise I have researched and written extensively on is development anthropology in Tongan politics and regional relations of the South Pacific. This does not make me a specialist on women. I have never taught university papers in women's studies. And, I do not see myself 
as expertly qualified to speak for women of small island developing states simply because I was born with female sex genitals, and have a New Zealand birth certificate, plus a New Zealand passport, where I am classified by the state as female by sex.

Women were being led where in Tonga's changing political landscape? Tonga intersected with delayed democracies of twentieth and twenty first century history; countries like the former states of the Union of Soviet Socialist Republics (USSR), who in the 1990s switched late to democracy as the world's preferred system of power. I intend this observation in the way that recognising the rights of women in developing countries of the global south is, in fact, a political movement instigated by developed countries of the northern hemisphere with established democracies and highly industrialised, capitalist economies.

Liberating women from patriarchal structures of domination, oppression and inequality is one of the Western crusades of modern times. First engineered in the United States and Britain in the 1960s and 1970s, it gathered impetus, spreading to the Western European continent. Retrospectively, feminist theorists write the women's movement as a global trend was politically manufactured and driven by middle class white women. Blinkered when it came to seeing through the whitewash of class and race privilege, the women's movement did not include, nor did it appeal to, poor women of the working class and underclass, women of colour, women of non-Western culture, and lesbian women (Naples, 1998).

Understandably Third World women, women from developing countries, poor women of colour from non-Western countries, whatever these women are labelled by bagging their inferiority in identity categories, find themselves in a paradoxical situation. In the case of Tonga, the push for women in parliament and government is a top-down project, and not one enforced by heads of the Tongan state 
bureaucracy. Really, it is the international power brokers dominating world politics, the United Nations and Western aid donor countries, propelling the agenda.

I have to ask for what reason? What does the West get out of converting the non-West to their political ideologies of modernisation and progress? Do they get a submissive world of mindlessly compliant non-Western countries and regions they can walk over by dominating trade and banking, and using their economic prowess as political leverage to manoever international relations?

Similar to the predicament of American and British women's movements of last century, lobbying the Pohiva government to put Tongan women in high office is of no consequence to poor women of commoner status. Why would women living on borderline poverty be interested in a political action group owned and represented by middle class women educated in Western universities, and employed as state bureaucrats or in non-government organisations functioning on, and accountable to, overseas donor funding? From the eyes of women inferiorised as Tonga's poorhouse, the middle class women of their country ramming a national women's movement down their throats were part of the established structure oppressing them, part of the problem, and were not the solution.

Instead, they would act as if they knew the answer by aggressively going after paid employment, money made off the backs of other women's misery. Propping themselves up to aid donors with funding as saving poor women from themselves, from their ignorant squalor, by providing a template programme on educating the uneducated women about women in power exacerbated, not alleviated, root causes of poverty and the unequal distribution of limited resources. This scene was overdone in real life on the not so Friendly Islands of Tonga. Again, the chorus sung from below was get real Tonga. 
In the next section, I have arranged excerpts from mine and Richard's journals we kept in Tonga during our fieldwork trip to scope and scan the Tonga election of 2014. The division of labour between us amounted to two distinct but mutually related roles. Richard worked the field, conducting conversations with a reach and range of Tongan and nonTongan discussants willing to share their observations, outlooks, and opinions on how the election would pan out, and what was required to move the country forward economically, as well as politically in relation to further democratic reforms. I got the desk job as the writer responsible for selecting narrative yarns harvested from Richard's fieldwork to interlace, and create a montage of words and meanings.

What I mean to say is the field research notes organised in this essay as journal entries by Richard in the part of the fieldworker, and me in character as the writer, along with selections of conversations in the field between Richard and a variety of speakers, should be read as a context-specific snapshot of a time, place, and people. It is, for the most part, a historical memoir of what we encountered, experienced, and lived through in Tonga for the election week of late November leading into early December 2014. It is not, by any means, an authoritative catalogue on all things the fieldworker and the writer must know and carry out piously to produce academic work like ours, to be just like us, and to parody our ways of engaging in, and making collective sense of, Tonga as a moving ethnoscape of people and politics (Appadurai, 1996).

\section{Snippet 1: Fieldworker's journal in Auckland and Tonga}

1. Richard Pamatatau - fieldworker in Auckland

As I left New Zealand for Tonga my onboard bag was 9 kilograms - 2 kilograms over the limit, and the Tongan official at Auckland airport looked at me and asked "where are you going today?" I said "Donga with a D not a T," and she replied, "fine, 
you have a nice flights and enjoy your time home." I am assuming she considered me Dongan and that my bag was topped up with goodies for the family or relations; all good.

I always like the Air New Zealand departure gate on the flight to Nuku'alofa. It is a place of expectation, departure, and reunion where the ordinary Dongan, the hafekasi [half-cast], the nobility, and senior servants mingle in a common space where there are technically no rank markers such as separate rooms or special treatment areas.

It is also a liminal space where people pass from one status to another with the grade of their ticket - the works, the works plus, seat and bag, seat only. It is also where the business crowd and tourists find themselves situated between wanting to make money from the Dongan government or people, and spend money on a low cost break, compared to say the Emirates or Singapore Airlines flights to Paris.

The flight was sort of amusing by the comment of a papa'aa [Cook Islands Maori reference to white/European person or people] businessman who referred to the plane as a "blane" clearly familiar with English spoken in a Dongan accent annoying, but also interesting because his interactions with ordinary Tongan people were very respectful. Maybe he is a working class lad who has done well for himself.

\section{Richard Pamatatau - fieldworker in Tonga}

After checking in to Seaview Lodge and taking my bags up, I sauntered to Friends café in town and had a flat white and a ham and tomato sandwich, which is always what I have on the soft fresh baked white bread.

The women in the café recognised me and asked if I was visiting Tonga for the radio [Radio New Zealand] to cover the elections. "Yes and no," I replied. But what was wonderful was the engagement and inclusion. They afforded me some tiny status as someone they remembered. More importantly, 
my function in the past as a journalist who I think they thought did a good job and whom they could trust was recalled.

"Were they voting in the election?" I asked. "Of course we are voting," they all said, "because we need to have a say in who gets in." On the election day they all voted and laughed at times during the conversation about the quality of candidates. "Clearly we need to get tourism up," they said, "because we are not busy at the moment." (Pamatatau, 2014a).

\section{Snippet 2: Writer's journal in Auckland and Tonga}

1. Teena Brown Pulu - writer in Auckland

Wanted to note, without lengthy ethnographic detail, that I had a massive argument on the telephone with Ma'afu in Tonga while waiting at Auckland International Airport departure lounge to board my Air New Zealand flight to Fua'amotu International Airport in the Kingdom. Massive, as in wound up and going hammer and tongs in stern disagreement. Election stress.

I sympathise fully that he is in a tight corner by putting forward a strong case to his class peers that the prime minister should be a people's representative in the Tongan parliament, and that it is not the right time in political history for the nobility to compete with the people for premier. Ma'afu disseminated the same opinion to local and Western media at the 2010 election, four years ago during the late King George Tupou V's reign as the Tongan monarch.

He soon turned tail and advocated for Tu'ivakano as premier once the nobility mobilised their bloc of nine parliamentary representatives to back their own class and kind in office, which I wrote about (Brown Pulu, 2014c, 2014d). In retrospect, quite possibly he regrets changing his mind and sees the 2014 election as an opportunity to have a people led government. However, it is manoeuvring around political fallout with ultra-conservative class peers like Vaea and Nuku who would oppose such a stand, and minimising the risk of splitting 
the voting bloc of nine nobles in the House, which takes some strategising and careful thought. ${ }^{7}$

What is a noble's role in a democratised Tonga? (Brown Pulu, 2012). I posed this inquiry almost three years ago with my first publication in the Ma'afu series of seventeen academic articles focused on political change in Tonga and the activity of the nobles in government during the Tu'ivakano term. Has the role of the nobility been transformed somewhat entering the new state administration from 2014 to 2018? I think it has, and that Ma'afu continues to be instrumental in orchestrating political stability between the class groups in parliament, and inside the country, amidst a shift in power to the people taking place. ${ }^{8}$

\section{Teena Brown Pulu - writer in Tonga}

On Wednesday evening of November 26th, the night before the Tonga general election, I arrived at Seaview Lodge around $9 \mathrm{pm}$, later than what I anticipated. Nia from Jetsave rentals was waiting patiently for me at Fua'amotu airport with the rental car when I disembarked from the Air New Zealand flight which was running late. This is the service prototype of Air New Zealand international flights dished up to Pacific Islander passengers headed home to poor developing islands, which sadly over the years I have become de-sensitised to.

Weird driving past my house at Haveluloto to sleep at a guesthouse in town like a white tourist. I actually felt like sleeping at home in my own bed in Granddad Stanley's master bedroom that he occupied when was alive. My maternal homestead is beautiful, peaceful, enclosed lawn, serene garden; added to that, I get a restful, blissful sleep there. Before I left Auckland mum said, "How nice to stay at a guest house for a change of scenery. I have often wanted to try the accommodation around the waterfront. It must be cool at night with the sea breeze." Shall adopt my mother's attitude and make the most of new surroundings, but if the cuisine is 
daylight robbery overpriced at the guesthouse restaurant and I can't find what I want to eat in the town cafés, I am going to the fish market and to buy fresh fruit and vegetables, and then home to prepare a proper meal.

Staff on the reception desk were lovely, all Tongans; although it was hard to understand their English and I was not entirely sure if any fully understood the questions I were asking of them while checking into my room. I refuse to patronisingly break down my English sentences into basic words and gestures for the simple reason that I am sure the staff speak perfect Tongan, and if they did think I was Tongan and communicated in their own language, they would certainly speak properly. But no one thought I was Tongan. No one ever thinks I am Tongan, not even in the town eateries and shops. The only folks around town who know I am of Tongan descent are those who know me like Paul Johansson, the owner of Friends café who is a distant relative on my father's side and my late paternal grandmother's neighbour.

A Tongan woman on staff asked if I wanted her to fetch the German owner of the guest house whom I had written to about my room booking, arrival time, charging the accommodation back to Orbit Travel, the university's travel agent in Auckland. She and her husband were located in a separate living area on the Seaview Lodge premises. Immediately I smirked at the visualisation in my head of "Upstairs Downstairs," the British television drama aired in the 1970s revealing the lives of the help (maids, servants, butlers) living downstairs to the Lord and Lady of the Manor hovering upstairs on a nobleman's estate. This was old mother England during the Edwardian era of 1901 up to the first world war of 1914 to 1918.

Tally ho. Rule Britannia. "There Ain't No Black in the Union Jack," as Paul Gilroy penned. Why is Tonga such a remnant of the British imperial past for me? I want to see Tongans own the pricier tourist lodgings and European help paid minimum wage to carry my suitcase upstairs to my room and fetch me an ashtray so I can smoke cigarettes on the veranda with a glass 
of wine at night scanning the people and landscape. Turnaround for the country and people if Tongans dominated the business sector. Sleep to greet election day tomorrow. (Brown Pulu, 2014a).

\section{Are we having a broader conversation?}

Richard coined a phrase in a book chapter about New Zealand media characterisations of Pacific Islanders that went, "And the silence is what lies in between" (Pamatatau, 2012, p. 189). He argued that in New Zealand society, mainstream media has a one-eyed view that all Pacific Islanders are good for is commenting on cultural festivals and deprivation stories of poverty and hardship. Outside of the alien nation, the Martian planet of festivity and deficiency Pacific Islanders inhabit as a critical mass which separates them out from the human species, they have no opinions. As Richard uttered, there is no "expectation they would even hold a view and would desire to participate in the broader conversation" (Pamatatau, 2012, p. 189).

This unsettles me, and it is appropriate that I do feel unhinged. I mean to say, what if field researchers and writers employed in developed country universities, like Richard and I, do not get it right, and by a worst case scenario, replicate Western myths and legends that Tongans can only speak to this, and not to that, when commenting on the politics of their own lives. Is a broader conversation on the Tongan governmentality of how a government glues together occurring at all? Why have Tongan expectations reformed in that merely holding up for four years in office like the former Tu'ivakano government is no longer good enough? 


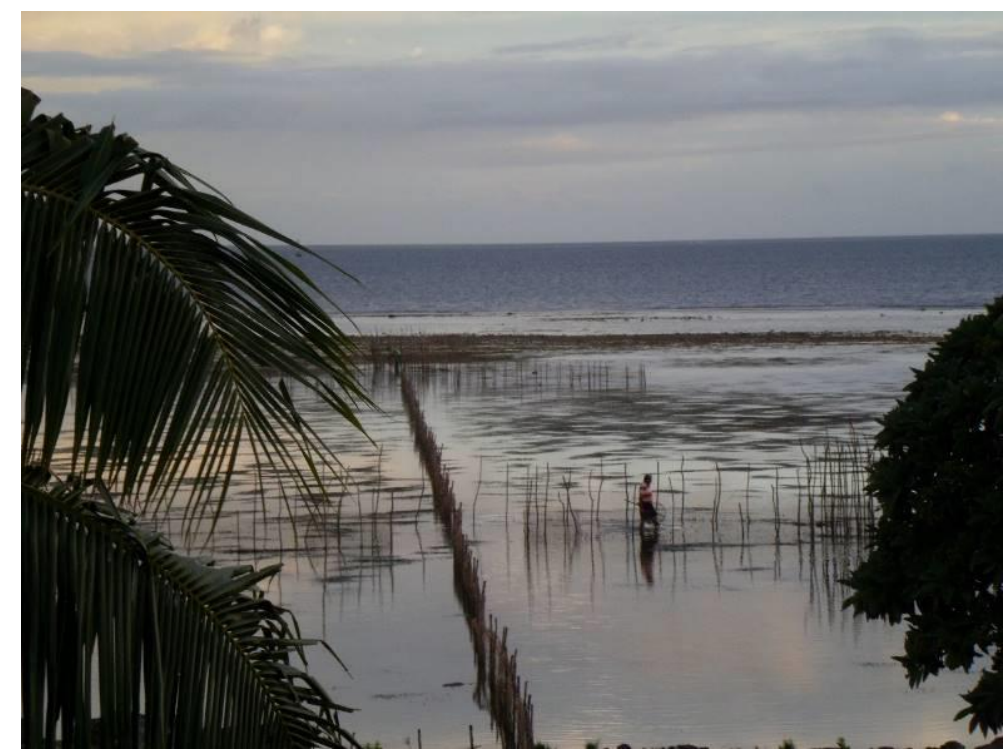

Photograph 3: A Tongan man gathering fish from a reef trap at dawn.

If there is a purpose in society that media and academia perform, then I throw out two jabs about what the objective might be in relation to reporting and research on Tonga. Are we inventing an identity category named ordinary Tongan people to preserve media's function in reporting news about them, and academia's occupation of analysing what they think, say, and do? (Kunelius and Renvall, 2010; Turner, 2009). For who are they - these nameless, faceless, ordinary Tongan people in real life - and is it ever truly feasible to "present and represent fairly some of the views of the population group?" (Pamatatau, 2012, p. 190).

The contrariness is that some (not all) nobles such as Ma'afu and Lasike have troubled the identity category of ordinary Tongan people by acting like them at selected times and in specific contexts, an ordinary person that is. Is this a Tongan example of performative identity? I am asking in light 
of Judith Butler's fashioning of identities, whether based on gender, race, culture, or class as socially constructed in ways that identity wearers feel compelled to perform the characteristics of a mould to gain acceptance and inclusion from insider affiliates (Butler, 1990). Tonga is a small, insular society where classes, cliques, circles, and clans are closed to outsiders that do not belong there. Who then can genuinely claim they do not want to be approved by their own people as one of them?

Judith Butler reframed the ontology ascribed to gender and sex in respect of how women and female were groupings constructed as the unchanging opposite to men and male by posing two interrelated questions. "Instead, we ought to ask, what political possibilities are the consequence of a radical critique of the categories of identity? What new shape of politics emerges when identity as a common ground no longer constrains the discourse on feminist politics?" (Butler, 1990, p. ix). Butler's reordering of identity discourse is relevant to interrogating how in Tongan state politics when power moves from the nobility to the people, such a shift causes a troubling of what have always been imagined as fixed, stable, and dualistic identity categories - the nobles versus the people (Butler, 1990).

To adapt Judith Butler's probing, what political circumstances constrain and constrict the two nobles Ma'afu and Lasike from staking an insider affiliation to, behaving like, and representing the interests of, ordinary Tongan people? (Butler, 1990). In Ma'afu's case, he found himself counteracting a volatile situation. Sternly he forewarned his class peers in the nobility if they did not retract Lord Vaea as their contender for the December 29th 2014 prime minister's election in the legislative assembly, he would vote against them. "I am crossing the floor," he boldly announced (Brown Pulu, 2014a). A declaration connoting transgression, Ma'afu was willing to deliberately step across boundaries enforced on 
him, where in the past, the nine nobles' representatives to parliament had voted staunchly as one unified bloc.

In noting this, I rephrase Judith Butler's words by asking, "What new shape of politics emerges when [Ma'afu showed us that class] identity as a common ground no longer constrains the discourse on [Tongan] politics? (Butler, 1990, p. ix). I bring up Ma'afu's will-to-act on his political conviction at various points and places in this essay for a noteworthy reason. The mode and manner in which he operated set off a momentous rupture to the conventional identity politics of Tonga's parliamentary sides. The borders had somewhat collapsed creating space on a once cramped stage of political actors. Instantly, they had a roomier area to intermingle, switch sides, forge new alliances with old antagonists, and to get to know others who although had been named and framed as the complete opposite to themselves, could now be conceived of as prospective collaborators.

Ma'afu had momentarily broken through categories of culture, class, and politics, and for doing so, was applauded by ordinary Tongan people for acting the part of a loose cannon, the lone renegade noble. The alternative reading of his performative public identity was that in the end, the nobility removed Lord Vaea from the race for prime minister. And thus, Ma'afu fitted back into playing the conservative noble politician by voting with the nine nobles' representatives for Samiu Vaipulu.

The deputy prime minister in the former Tu'ivakano administration and an independent people's representative for Vava'u constituency number 15, Vaipulu lost the election against Akilisi Pohiva, 11 votes to 15 . He did not have the supply and confidence of his peers, the independent people's representatives, who crossed him out when it came time to tick the box on the ballot paper. Which brings me to query, why would the nobility pick Vaipulu as their common man to stand for prime minister over other independent parliamentarians with their hands up who seemed more 
palatable to the public, and carried less history and excess baggage?

Speculation swarmed around Tonga that Ma'afu voted for Vaipulu because he had been tipped off that five of the seven independent people's representatives were migrating to Pohiva's camp. Gossipers surmised he knew beforehand the Democratic Party alliance of ten in the House had the numbers stacked to win the premier's election and lead a coalition government. However when I spoke with Ma'afu on the telephone, with him in Nuku'alofa and me in Auckland straight after Pohiva was confirmed Tonga's prime minister on the afternoon of Monday the 29th of December 2014, he opened up on why he voted with the nobles' bloc.

Ma'afu: I wanted to stand with the nobles. My concern was Vaea running for prime minister. I made it clear I would have crossed the floor if that had been the case. Once he was revoked, I had no qualms with whoever from the people's representatives was running in the election. The main thing is that a politician from the people gets to become the prime minister. I am happy for my uncle ['Akilisi Pohiva], but sad for Samiu [Vaipulu].

As for your question about why Samiu [Vaipulu] was chosen, well, there were other names put up for consideration. I even put up 'Akilisi's name. But once the nobles agreed on one name, then that was who we would vote for. Your uncle [Siale'ataongo Kaho] kept coming back to the nobles with various names, including his own. I wasn't at the meeting when that happened. But my view is we must be stable and stand solid behind Samiu [Vaipulu] because in all fairness, he was who all the nobles chose to support. We can't change from one person to the next, from one day to the next, because that is unfair to whoever it was we first agreed to endorse at the prime minister's election. Further to that, going all over the place is inconsistent and splits the nobles.

I wanted to stand with the nobles because our role in parliament is to protect His Majesty [Tupou VI] and the 
constitution. The King is our life, and we are His Majesty's nobles here for King and country, here to protect Tonga and the people. It is the culture. You will say [in character, he imitated my female voice pestering him], "Oh but Ma'afu, what about this, and don't you know that Ma'afu? Have you read this paper, and that book, and the next thing Ma'afu?" I do know what I am doing. I do read a lot. I have thought about the future of Tonga. This is what I know is best for the country. You and I argue. That is life.

Ma'afu's assertion that "I am crossing the floor" shook the political dividing line separating the nobles out from the people's representatives of a pro-democratic stand (Brown Pulu, 2014a). By this, it is true that the nobles did not vote for 'Akilisi Pohiva in the prime minister's election at parliament on Monday December 29th, 2014. But it is untrue to say that as a bloc of nine nobles' representatives, who in turn align their politics with the monarch, they have unanimously averred never to lend support to the Pohiva administration. Although their backing would more than likely be selective and pointed at government bills entering the House and policies corresponding with what is seen as the nobility's position, my point is, politics in Tonga has changed causing the old dichotomy of nobles versus people's representatives to adapt in an altered political climate.

Unravelling the Ma'afu narrative is purposeful. His voice is read against background noise. In the public domain, the Tonga election of 2014 was accounted for by journalists and academics, and what they thought really happened. Compared to the public commentary parties representing media and academia, Ma'afu's voice stands out for an explicit reason. Put simply, he knows what he knows. When I asked him to explain what he knows, and why he knows this to be true, he is eloquent, confident, and willing to perform the role of an insider voice.

Ma'afu understands when he speaks to me I am situated outside of his inside position. He knows I am an 
anthropologist, a researcher and writer in a New Zealand university, and a woman of Tongan ancestry who does not permanently reside in Tonga, the country where he lives and works daily. He tailors his voice and language to be clearly understood by me in English, my Native tongue as a half-cast in Tonga. He wants to alleviate any risk I might warp what he has said by writing a misguided story that discredits the authenticity of his voice.

My argument is that Tongans do understand who they are speaking to. More importantly, they know if field researchers, whether journalists or academics, can be trusted to respect the authenticity of their voices by not speaking over them as self-important, puffed-up authorities on other people's lives. The following section is called voices from the field. These are excerpts from Richard's field research notes in Tonga narrating some of the conversations he had on the week of Monday 24 November to Monday 1 December 2014. Two interrelated insights show up in the dialogue exchanges between the fieldworker, and the people being asked to share their views and validate their voices.

First, the six people selected here are doing identity work by their own rationale of relating themselves and their voices in respect to the Tonga election 2014. Second, the fieldworker is a political actor appearing on stage with the cast too. He is not the feature act in the script. None the less, Richard Pamatatau is a real character whom the people he is speaking to know. Contextually, their knowing infers the speakers and Richard have formed the kind of fieldwork relationship where they expect him to appreciate that their judgements about the people and politics of Tonga are honest and reliable.

Worth noting is that one speaker I have cited from Richard's field research notes is a Pakeha (white) male New Zealander living and working in Tonga. He has New Zealand citizenship not Tongan citizenship, which meant he was ineligible to vote in the Tonga election of 2014. He held to a deep-seated belief the New Zealand government's involvement 
in Tonga's development as a small island developing state was based on Tonga being a "strategic country in the Pacific Islands' region for New Zealand and the West" (Pamatatau, 2014b).

The New Zealander's patriotism to his own country "and the West," meaning an American driven world order, has to be read against Tonga Prime Minister Pohiva's inaugural address to the state civil service, televised to the nation by public broadcaster Television Tonga on Friday afternoon of January 9th, 2015 (Pamatatau, 2014b). Pohiva doggedly affirmed a policy shift was to take effect under his coalition government: "If Tonga's budget was managed properly, the economy could become stable. This would lead to vigorous economic growth and mean less reliance on overseas donors" ('Akilisi Pohiva cited in Latu, 2015a).

In brief, the Pohiva government was introducing austerity measures to the state budget, enforcing strict cut-backs on national spending with the overarching objective of weaning the country off aid dependency. Where did that position "New Zealand and the West" in the international donor regime of wrangling China and South East Asia for control of "Tonga [as] a strategic country in the Pacific Islands' region?" (Pamatatau, 2014b). Tonga had a different foreign affairs minister, the present prime minister, who came with a novel approach to international relations. Was it at all likely that New Zealand would change its entrenched attitude and behaviour to doing aid, trade, and diplomacy in Tonga?

\section{Voices from the field}

\section{Two Tongan hotel workers}

The cleaner at Seaview Lodge, my accommodation during election week, talked about having gold teeth as a tribute to her late mother. She regretted it, but there was nothing she could do now. The family wanted her to have it done: "That's what we do in Tonga; we listen to the family." But she did say that 
she is making sure her children do very well at their education because that way, they will get good jobs and move away from Tonga if they want. There is nothing for them here in Tonga, and she does not want them to do what she does for a living, clean hotel rooms. But she also wants them to be good Tongans, and so development comes down to a mix of Tongan culture, learning to communicate well in the English language, and Western-oriented education.

By comparison to the cleaner were ironic views shared by the receptionist at Seaview Lodge who works for $\$ 25$ pa'anga [Tongan dollars] a day. She told me she will vote for Akilisi Pohiva because he is a good man. But, she does not believe in human rights, and thinks it is good for her to get a beating from time to time from her husband, and in the past from her late father. Getting a beating from her husband and father teaches her respect, and that is what she wants her kids to learn too.

\section{New Zealander working in Tonga}

Prior to the election, he expected either a noble or Samiu Vaipulu, who was the deputy prime minister in the Tu'ivakano government, to be the new prime minister of Tonga. He did not think Akilisi Pohiva was physically well enough for the rigorous demands of the premier's job. But whoever got in, he felt that the New Zealand government would work hard to support them because Tonga is a strategic country in the Pacific Islands' region for New Zealand and the West. He did not agree that New Zealand had lost some of its clout in the Pacific Islands region, but he did not dismiss it outright either.

He noted with the coronation of King Tupou VI in 2015, there was no way New Zealand could compete with the 35 vehicles that China was giving Tonga for the occasion; 3 of them were mini buses or vans, 2 were substantial cars, and the remainder were cars for transporting dignitaries, which after the coronation would be gifted to the people. I was not sure whether he meant the cars would be gifted to ordinary Tongans 
chosen by the state, or gifted to the various government ministries for their use as state bureaucrats of the public sector.

He also made a point of saying that China had donated 3 Jaguar type cars to Tonga which were to be used for government business. Somehow, they ended up in private hands, including one which was driven by the wife of the outgoing Prime Minister Tu'ivakano at the November 27th 2014 election, Lady Robyn Kaho. He thought the New Zealand government would more than likely offer to the Tongan state as a 2015 coronation gift more education scholarships for students to attend New Zealand universities and technical institutes.

\section{Tongan journalist}

Change is needed from the nobility, and part of that is land reform too. We need a whole reform movement. This is prodemocracy in Tonga, and it will have to take place in the legislature. It means removing the assigned seats from the nobles where they vote for each other, and instead, getting the people to vote for them.

Various districts and constituencies have signalled change is happening. The King is with the people as is his wife, along with Lord Ma'afu who says the prime minister is not to be a noble, but rather, has to come from the people. The political is intertwined with the personal and the social, and we need to observe this. It is a difficult dynamic for outsiders, Westerners such as the New Zealand government officials in particular, to understand and come to grips with. Also, the influence of the church cannot be discounted from now and into the future of politics, especially the Mormons, as the King's youngest son is going down that road by joining the Church of the Latter Day Saints. 


\section{Tongan retired school teacher}

Everything about the election matters to Tonga. The nobles in the political arena must be elected by the people as the system develops. That will show a true respect for the culture in the political arena as we need a declaration. "But how will the nobles react?" I asked.

He responded that they are mixing their political power with their cultural power, and that needs to be looked at. People will still respect them in a cultural sense. They have nothing to worry about in that area, and there are the matters around land. There are benefits to having nobles voted into parliament by the people for resolving land matters, and that is positive.

The big concern in the political arena follows what is being discussed internationally. That is, there are two alternatives open to the people. First, the nobles can keep their nine seats in parliament, but they have to be voted in by registered voters on the general electoral roll and not voted in by themselves as an elite group of nobles. Alternatively, they can stand as candidates for the general election and compete with all the people running for parliament. He saw these two options are much more transparent, and the nobles need to go with the people and not work against them.

As for the nobles' other privileges guaranteed in the Tongan constitution, they will still enjoy them because the culture will allow that to happen. But an electoral system that is further reformed means in the political arena they will have to work hard to earn the respect of the people, and not just rely on the nobility's privileges to get by. In other words, many of their cultural privileges should not be directly linked to the political arena, especially to foreign affairs and international politics of the Pacific Islands region.

There is a lot of confusion in Tonga, and the main push should be to educate all Tongan people on the differences between political and cultural issues. The nobility has to realise that if they are elected to parliament by the country's registered voters then they will have the respect of the people and be 
taken care of. These are the broader issues that Tonga must face and deal with, or else they will grapple with the issues and risk greater confusion from not resolving them. As it stands though, he said that Akilisi Pohiva has to learn that new blood is needed to groom the next generation of parliamentarians and the country's political leaders.

5. Noble who was not elected to parliament

During the nobles' election at the Palace Office, this particular noble came outside to sit under a tree with the local Tongan media, and began chatting away in a cordial manner. His driver brings him a cigarette and bottled water to drink. He tells me the challenge for the incoming government is to clean up all the ministries because they are all in a situation of chaos. The wages are so high that Tonga cannot afford it, and someone must be made accountable for the financially dire circumstances of government. If that is sorted, then you can use small stepping stones to make the foundation of the state bureaucracy strong.

There was banter between the noble and a Tongan woman about his new baby to which he replied, "Do not judge me by the colour of my beard!" His beard is greying, and the pun was that he might look as if he is aging but obviously, by the birth of his new baby, he is not.

At this moment, two election observers from the United Nations Development Programme (UNDP) arrived and barged in to interrupt our conversation by asking the noble random questions disconnected from a Tongan social context. The male of the two UNDP officials took a very patronising attitude towards the noble, although he probably had no idea that his behaviour was read as the kind of condescending treatment Tongans are used to getting from Europeans and feel affronted by.

"What do you do, and are you based here?" asked the male representative of the United Nations Development Programme in 
his official tone and tenor. He had no clue he was addressing a Tongan noble. "Me? I am a planter and I get my hands in the soil," answered the noble in a tongue-in-cheek manner that flew over the European's out-of-place demeanour. "What do you grow? Do you grow coffee?" continued the European, dogmatic about following his line of questioning to get the answers he wanted. "Coffee is not really available anymore. But I just grow things, and the heat has not really come yet," chatted the noble. He was acting his friendly planter role on stage with the European authority who had landed in Tonga from another world, another planet, another place in a galaxy far, far away. (Pamatatau, 2014b).

\section{One noble}

Lord Ma'afu's appointment to the Pohiva government in the lands and defence portfolios appeared to be low-key inside Tonga. Many expected that he would retain his ministerial seat at the cabinet table for a number of reasons. In the former Tu'ivakano administration, he kept away from trouble, and was never publicly condemned for botched decisions that backfired. When he was hurled on centre stage of parliamentary live theatre, the plot was clear-cut; railroading legislation, like the Tonga Seabed Minerals Act 2014, straight through the House without any obstruction. He lived up to that role.

Underpinning this was Ma'afu's stand that if the nobles did not withdraw Lord Vaea as a contender for the prime minister's election on November 29th 2014, he was crossing the floor to vote for the people's representatives' nominee (Brown Pulu, 2014a). Ma'afu dared to vote against the nobility to ensure the people held down the numbers to elect Tonga's first commoner premier; a position he voiced at the 2010 prime minister's election, but was overruled by the nobles' voting bloc doggedly pushing for Lord Tu'ivakano to take first prize from Akilisi Pohiva. Added to this, was the fact Tonga's 
newly elected Prime Minister Akilisi Pohiva was a patrilineal uncle to Ma'afu, and their dependable relationship could be counted on.

Should I erase the last sentence to deescalate the risk of publicising a family bond that Western readership might onesidedly smear with conflict of interest? No, for a contextspecific reason worth bringing up here. Tonga is located in a global economy. The people and place are not isolated from the rest of the world; nor are they detached from Western countries and cultures. But the country itself does remain a small island society where bloodlines, kinship ties, and clan connections fundamentally determine relationships between human beings, shaping the way a person, or a people, become characterised. Comprehensibly then, a conventional Tongan wisdom expressed in everyday conversation is if you cannot trust your own family, your own blood, then who can you trust?

An email I received on December 31st 2014, straight after the Government of Tonga press released Prime Minister Pohiva's announcement to the public of cabinet ministers for the 2014 to 2018 term was telling (Government of Tonga, 2014). The correspondent was a long time Tonga prodemocracy supporter, and a prominent Tongan and Pacific Islander community leader in New Zealand. He wrote, "I am heartened by the new Cabinet lineup, especially with Ma'afu as the only noble in Cabinet. Ma'afu has earned his place in more ways than one. $\mathrm{He}$ is the most capable and most transparent operator from the nobility, so he has the creds [credibility]" (Anonymous Correspondence, 2014).

The point I want to make is if widespread opinion across class groups in Tonga, and even among the die-hard backers of the pro-democracy movement is that "Ma'afu has earned his place in [the Pohiva cabinet and] has the creds [credibility]," then how could this be misconstrued as a problem? (Anonymous Correspondence, 2014; Tonga Herald, 2014). What I am nodding at is the cultural illiteracy and lack of 
knowledge of not singly Western media, but Tongan news operators in New Zealand when it comes to misreporting and distorting what is really taking place outside of their domestic territory, and inside Tonga.

Kalino Latu exemplified this point. As the owner and publisher of an Auckland Tongan news website New Zealand Kaniva Pacific, he got his facts completely fuddled. Latu assumed Ma'afu, a high-ranking noble who was the Minister for Lands, Survey, and Natural Resources in the former Tu'ivakano government only got given his job back by the current Prime Minister 'Akilisi Pohiva because the constitution specified "one of the king's nobility" must be appointed the role (Latu, 2014a).

Lord Ma'afu could have been only elected as one of the cabinet ministers because [the] Tongan constitution stipulates that a minister for Land and Survey portfolios must be from one of the king's nobility. (Latu, 2014a).

Latu's claim was not true. If he had read the amendment to Tonga's constitution stating that "one of the representatives of the nobles" must hold the "Minister of Lands" portfolio, he might have noted this was for "the first four year" term of government after the 2010 election. Once the Tu'ivakano administration vacated office in 2014 the ruling no longer applied allowing any member of parliament - noble or people's representative - to assume the ministerial position.

Provided that, subject to the Constitution, after the general elections in 2010, the Minister of Lands shall be appointed from one of the representatives of the nobles, and provided this proviso shall cease to apply at the expiry of the first four year session of the Legislative Assembly. (Government (Amendment) (No. 2) Act, 2010, p. 5). 
The truth was the Democratic Party adopted a conciliatory tactic to modelling a coalition consisting of what appeared to be a representative government. With twelve ministers of six Democratic Party parliamentarians, including the prime minister, the five independent people's representatives who had voted for Pohiva at the prime minister's election, and one noble chosen by the head of government, the idea was that "we still want to be seen as a united Cabinet" (Radio New Zealand, 2014b).

We need to include one of the nobles in Cabinet because we still want to be seen as a united Cabinet in which representatives of the people and representatives of the nobles can work together from now on. ('Akilisi Pohiva cited in Radio New Zealand, 2014b).

Being "seen [to the public] as a united Cabinet" was the political tranquiliser, as opposed to a stabiliser, which sedated the opposition in the House (Radio New Zealand, 2014b). Earlier in this paper I cited Sefita Hao'uli saying that "the opposition that is needed for our democracy needs to come from "We, the people" now, because there is no organised political opposition at present" (Hao'uli, 2015). Sefita's logic was that "We, the people are better mandated than the nobles to point out to government what they are doing wrong [and also, the Pohiva cabinet] are more likely to respond to challenges from We, the people" (Hao'uli, 2015).

There was cultural truth to Sefita's suggestion that an effective challenger to government policies might be members of the general public, expressly lobby groups organised for specific causes. To illustrate this, the Tongan Women in Action Collective coordinated by the director of Tonga's Women and Children Crisis Centre, 'Ofa Guttenbeil and her 
collaborators, came together exclusively to pressure the premier to include a woman in cabinet (Hill, 2014b).

On January 3rd 2015, "a petition ... with 416 signatures calling for the PM [Prime Minister] to consider using his prerogative under [constitutional] law to appoint a woman to a Ministerial Portfolio" was delivered to his home in Kolomotu'a, Tonga (Tongan Women in Action Collective, 2015). The collective's press release issued five days later on January 8th 2015, conveyed Akilisi Pohiva's reply was welcomed as a positive indication that pressing their case had made an impression on him. "Come up with legislation to change the situation," said Prime Minister Pohiva (Tongan Women in Action Collective, 2015).

Did a brief sentence, "come up with legislation to change the situation," guarantee a bill of constitutional amendment that permitted women to be permanently structured into cabinet's composition would be taken to parliament by the Pohiva government, and subsequently, sanctioned into law by King George Tupou VI? (Tongan Women in Action Collective, 2015). The short answer was most definitely it did not.

However, this was the political product of being "seen [in the public eye] as a united Cabinet" that is "more likely to respond to challenges from We, the people" (Radio New Zealand, 2014b; Sefita Hao'uli, 2015). Akilisi Pohiva was performing a lead role of executing smart moves on the political chess board. Persuasive politics in democratic arrangements did, in many instances, boil down to publicly staging the semblance and sensation that government was taking up the schemes and dreams of various pressure groups. The theory behind this practice was keeping the voters happy in the way that those who have bought into a certain ideal of liberal democracy expect the voices of "we, the people" are heard at high office, and taken seriously (Hao'uli, 2015).

Returning to Pohiva's rational for including the one noble Ma'afu in cabinet, he felt "the nobles need a sense of security" 
seeing a Democratic Party led government had assumed office (Fonua, 2015).

With the selection of Lord Ma'afu as the Minister of Land and Natural Resources, and the Minister of His Majesty's Armed Forces, 'Akilisi said he made that choice because "the nobles need a sense of security." ('Akilisi Pohiva cited in Fonua, 2015).

What exactly did Tonga's prime minister imply by using the phrase, "a sense of security?" (Fonua, 2015). Outwardly his testimony referred to the nobility's displaced and somewhat unstable position in a parliament dominated by a people's led government operating under Democratic Party directives. Inwardly, however, Ma'afu's location inside cabinet gave the Democratic Party coalition "a sense of security" (Fonua, 2015).

Undoubtedly, Ma'afu lent the Pohiva government weight and influence among the royal household and the nobility. A greater likelihood ensued that the monarch would be open to dialogue with the prime minister given the noble of Vaini and Tokomololo assumed the lands and defence portfolios, and could, if need be, put the brakes on legislative reforms conjured up at cabinet's talk table that might threaten to diminish the King's constitutional rights and privileges.

\section{I am making trouble}

To make trouble was, within the reigning discourse of my childhood, something one should never do because that would get one in trouble. The rebellion and its reprimand seemed to be caught up in the same terms, a phenomenon that gave rise to my first critical insight into the subtle ruse of power: The prevailing law threatened one with 
trouble, even put one in trouble, all to keep one out of trouble. Hence, I concluded that trouble is inevitable and the task, how best to make it, what best way to be in it. (Butler, 1990, p. vii).

To conclude, I have threaded carefully chosen pieces of Richard Pamatatau's field research notes in Tonga of the 2014 election into my overall analysis. Created is a moving mosaic of who's who caged up in a renovated political zoo. In all honesty, I have written this essay to make trouble in Tonga. My ancestral homeland needs troublemakers, wrote the female anthropologist of part European and part Native Tongan ancestry, largely directing her comments to a male dominated South Pacific Kingdom organised by rank and hierarchy. Tonga is a small island developing state, where women gain the attention of men in power if they meet international funding criteria on what type and class of women foreign donors and banks require in key state bureaucracy roles to develop their programmes on helping themselves, and their kind, to our country.

Ouch that stung; let me start the end of me again. Tonga needs critics, thinkers, writers, and artists with know-how on destabilising too easily accepted identity categories, which were never fixed and immovable to begin with. For it is all too widely thought by Tongans themselves that predominant identity categories are swallowed hook, line, and sinker by gullible people over-socialised to accept what the establishment drills into them, without questioning and challenging that very authority's morality and judgement.

"Hence, I [have] concluded that trouble is inevitable and the task, how best to make it, what best way to be in it," wrote Jewish American scholar Judith Butler twenty five years ago in the last century (Butler, 1990, p. vii). I agree. Tonga has taught me "how best to make [trouble], what best way to be in it" without getting crushed by the weight of angry Tongans who do not approve of a hybrid, half-cast woman from 
overseas up in their face about Native business she only has part (not full) claim to know, speak, and write of (Butler, 1990, p. vii). Tonga has taught me well. The endnote that follows are mine and Richard's journal musings on privilege, our own mostly. End of story.

\section{Endnote: Fieldworker and writer reflect on privilege}

\section{Richard Pamatatau - the fieldworker in Tonga}

The people in the [Talamahu] market were less than excited about the election. They all said they were going to vote. I don't know if they did but what they all made clear was they needed a lot more tourists to come through and buy goods from them, in the craft section especially. I did wonder how much people managed to sell off their fresh produce and whether the cost of production was met by the cash amount that items were sold for. The luscious piles of tomatoes, capsicums, carrots, citrus, spinach, cabbage, manioke, breadfruit, bananas, coconuts and oils are stunning, but also very cheap. I probably needed to spend more time in the market but was conscious that as I was not buying anything, I felt a bit like a looter.

I have been struck this time by Tongan enterprise - brooms, fish, jelly fish, fruit, produce - sold at roadside stalls or shops with the owners sitting outside all day; sometimes under tree shelter; sometimes under a tent; sometimes in the hot sun. Everyone I spoke to was friendly and aware of the election, and were going to vote or had voted and hoping for a better government to make a better economy.

I did find my stay at Seaview Lodge problematic so I made sure that minimal work was needed to be done to my room each day. All I asked for was a change of towels and extra coffee as I did not want women working for $\$ 25$ pa'anga [Tongan dollars] a day cleaning up after me when that is what it would cost for a sandwich in the afternoon from the hotel restaurant, or for coffee and cake at Friends or Escape cafés in town. I also left, 
in an obvious way, unopened biscuit boxes, toothpaste, and soap for the women looking after my room, plus milk and water in the refrigerator.

Was this patronising of me? Did I disempower them? I think that next time I will buy milk and not open it, plus extra grocery items as a courtesy for the pleasantries we exchanged. I discussed this with Dick Bedford, AUT University's longest standing fieldworker in the Pacific Islands region of over forty years, who says he always leaves coin change too.

I note this because I took 23 kilograms of luggage and 9 kilograms of carry-on luggage with me on the Air New Zealand flight to Tonga. I had two shirts for every day, and two jackets and pairs of shoes. All of the women wore the same uniform every day, and I noticed the black thread holding together frayed edges of their dress seams. (Pamatatau, 2014a).

\section{Teena Brown Pulu - the writer in Tonga}

Early on Thursday morning of November 27th before starting out in the field to see how people were feeling and talking, and what they were actually doing on election day, I dropped my maternal first cousin's Duty Free bourbon and cash that I had for him at his workplace, the main office of Fiji Airways in Ma'ufanga. Our mothers are sisters, Deanne and Patricia Brown, and Carstein is the closest family I have living and working in Tonga.

I am indebted to my cousin for living in our maternal homestead, an old 1950s Copra Board house assembled in New Zealand, which has seen better days when our grandparents Stanley Brown and 'Ana Kaho were alive in the 1970s. Carstein is satisfied to permanently reside in Tonga, rather than plot his breakout of the Kingdom for a developed country salary in Auckland or Sydney. For this, I can exhale sheer relief that we do not have to rent out the old homestead to Chinese immigrant tenants. I say Chinese lodgers because it is no national secret that Tongans might in fact struggle to pay the 
rental fee. Considering it is their country and the majority of people are poor and living on the borderlands of poverty, I would feel horrible taking any Tongan to task to recover rent money.

As always when I return home to Tonga for six to eight trips annually, he was delighted with the money and to have good quality Bourbon. We often joke the cheap vodka imported from China and sold over the counter at local stores is petrol, meaning it is poor quality liquor and we feel sorry for Tongans who drink it risking liver damage and alcohol related noncommunicable diseases because it is the only top-shelf spirit they can afford.

Pulling up to Carstein's workplace he texted me, "Teena, I am at work now. I am at my desk." I retorted, "I know that. I am sitting here looking at you. I am trying to find a park. Only in Tonga do local fishermen take over the public car park and cars have to park somewhere else." The car park adjacent to the Fiji Airways office was being used as a fish market by local street vendors manning their stalls. They set up for the day early in the morning before the government and private sector offices open for business at $8.30 \mathrm{am}$. The marketing strategy is to catch sales from consumers commuting to work in vehicles. 


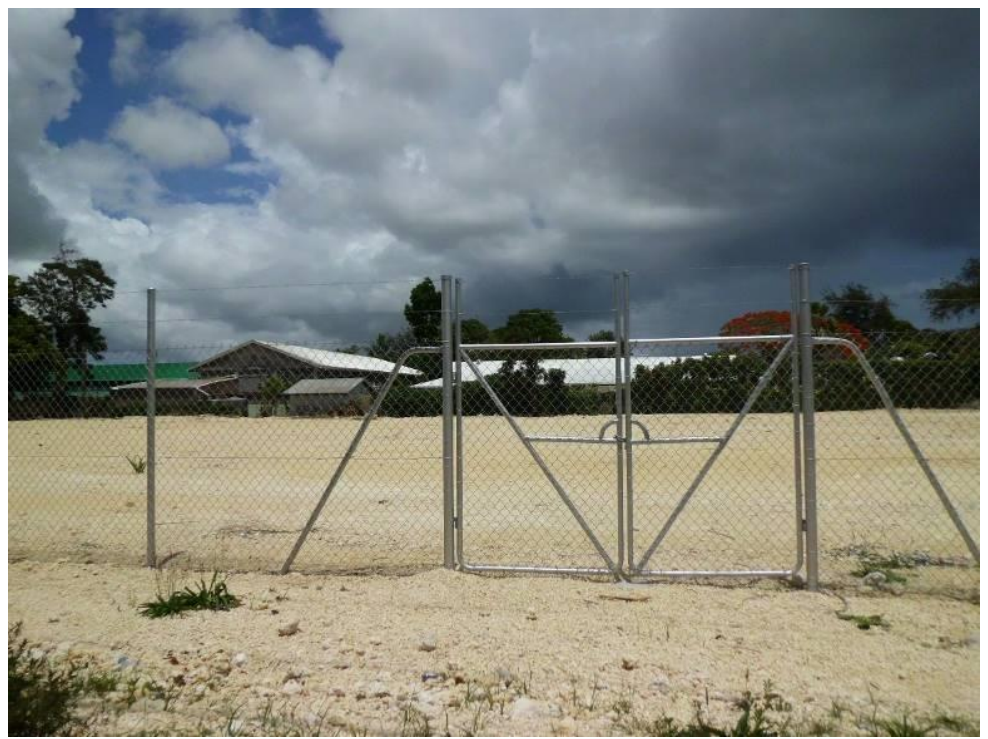

Photograph 4: The cage on Vuna Road designed to capture street vendors.

Is this method of doing business effective for fish sales? No, to be frank. But what options are there for poor people to generate cash income apart from informal trading on Vuna Road, a main thoroughfare for traffic on the foreshore that fronts the capital? Vuna Road is saturated with street stalls, as was Taufa'ahau Road southbound from Nuku'alofa to Fanga-oPilolevu on the urban outskirts of town. There are not enough buyers to street sales men, sales women, and sales children, as often families are perched together under make-shift tarpaulins and tents for shade, vending fruit, vegetables, seafood, firewood, and handicrafts to supplement the meagre household budget.

I am obsessed with the cage, the outgoing Tu'ivakano government solution to sweeping the street vendors off Vuna Road and concealing them from the sight and sensitivity of sanitised white tourists who might balk at poor peddlers darkened by the sun. There is still time before the polling 
booths open at 9 am, and I am parked outside the cage, staring from the open driver's window, snapping photographs of the wire enclosure, padlocked gate, and daylight shimmering on sheets of sun bleached limestone laid down inside the perimeter.

How any minister or bureaucrat in high office could think it is acceptable to contain human beings inside the cage under work conditions of 30 degree heat without access to water, shade, and ablution facilities is beyond humane reasoning. How any government could charge Tongan people a fee to be locked up in the state's street vendor jail is a bureaucratic culture drenched and dripping in iniquity and inequity.

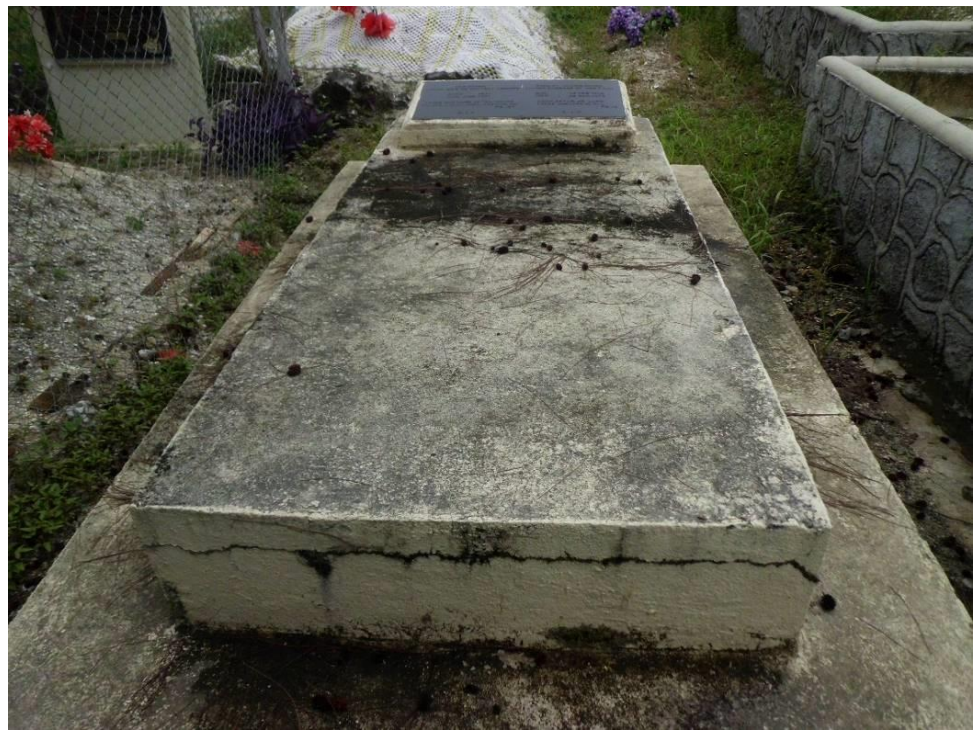

Photograph 5: The grave of Stanley Hosier Brown, British citizen and Teena Brown Pulu's maternal grandfather buried at Haveluloto village in Tonga, a few houses down from the Brown family homestead.

Some mornings, I feel sick waking up in Tonga. I get migraines in the heat obsessing over the establishment's 
unethical treatment of Tongan people. But I always come back to see the ancestral homeland, even though I can choose not to as an adult. The truth is my warm childhood memories of summer holidays at Granddad Stanley Brown and Grandma 'Ana Kaho's homestead in Haveluloto tug at the heartstrings. Social memory tells my political conscience to care deeply about this country of coral islands, and the proud, spirited people darkened by working in the sun who have lived here for centuries.

"Come writers and critics who prophesise with your pen, and keep your eyes wide, the chance won't come again. For the times, they are a changing," sang a young Jewish American musician Bob Dylan in 1964 to support the Black civil rights movement in the United States. For now, I will hum along too. Change will come to Tonga, in my lifetime. (Brown Pulu, 2014b). 


\section{References}

Akel, T. (2015). Tonga 'overdue for change' - community leader. 3 News: Television New Zealand, Auckland, New Zealand, January 4, 6:05 pm.

Anonymous Correspondence. (2014). Anonymous correspondence via email communication to Teena Brown Pulu, Auckland, New Zealand, December 31 .

Appadurai, A. (1996). Modernity at Large: Cultural Dimensions of Globalization. Minneapolis, United States: University of Minnesota Press.

Brown Pulu, T. (2014a). Who's who in the zoo? Tonga election 2014. Published in Hamilton, S. (2014). Teena Pulu Brown rattles Tonga's cage. Reading the Maps, New Zealand, December 15.

Brown Pulu, T. (2014b). Journal entries on Tonga fieldwork, 26th to 29th November 2014. Auckland, New Zealand and Nuku'alofa, Tonga, November 26-29.

Brown Pulu, T. (2014c). Clash of Civilisations: Tonga and the West. Te Kaharoa: The e-Journal on Indigenous Pacific Issues, 7 (1): 254344.

Brown Pulu, T. (2014d). Minerals and Cucumbers in the Sea: International relations will transform the Tongan state. Te Kaharoa: The e-Journal on Indigenous Pacific Issues, 7 (1): 383474.

Brown Pulu, T. (2012). Ma'afu's word is in the hills: What is a noble's role in a democratised Tonga? Te Kaharoa: The e-Journal on Indigenous Pacific Issues, 5 (1): 138-208.

Butler, J. (1990). Gender Trouble: Feminism and the Subversion of Identity. New York and London: Routledge.

Clifford, J. (1988). The Predicament of Culture: Twentieth-Century Ethnography, Literature and Art. Cambridge, Massachusetts, United States: Harvard University Press.

Dylan, B. (1964). The times they are a changing. From the Album, The Times They Are-A Changin,' by Bob Dylan. New York, United States: Columbia Records.

Fonua, P. (2015). 'Akilisi sets a high moral goal for his government. Matangi Tonga Online, Nuku'alofa, Tonga, January 2. 
Fonua, P. (2014). General Election challenges voters to save Tonga. Matangi Tonga Online, Nuku'alofa, Tonga, November 12.

Gilroy, P. (1987). There Ain't No Black in the Union Jack: The Cultural Politics of Race and Nation. Illinois, United States: The University of Chicago Press.

Government (Amendment) (No. 2) Act. (2010). Government (Amendment) (No. 2) Act 2010: Act No. 48 of 2010. Legislative Assembly of Tonga, Nuku'alofa, Kingdom of Tonga, September 28, Pp. 1-6.

Government of Tonga. (2014). Media Release: Prime Minister Announces New Cabinet Ministers. The Prime Minister's Office, Government of Tonga, PO Box 62, Nuku'alofa, Kingdom of Tonga, December 31.

Hamilton, S. (2014). Teena Pulu Brown rattles Tonga's cage. Reading the Maps, New Zealand, December 15.

Hao'uli, S. (2015). Facebook post from Sefita Hao'uli to Teena Brown Pulu, Auckland, New Zealand, January 8.

Hao'uli, S. (2014). The sentiments for a commoner. Matangi Tonga Online, Nuku'alofa, Tonga, December 4.

Hill, B. (2014a). Petition to appoint women directly to Tonga's cabinet. Pacific Beat: Radio Australia International, Melbourne, Australia, December 31.

Hill, B. (2014b). Tonga election likely to focus on economy. Pacific Beat: Radio Australia International, Melbourne, Australia, August 20.

Hill, B. (2013). Still a desire for political change in Tonga says academic. Pacific Beat: Radio Australia International, Melbourne, Australia, October 30.

Kaniva Pacific. (2014). Democrats and independents agree to form Tonga's next government. New Zealand Kaniva Pacific, Auckland, New Zealand, December 3.

Kunelius, R. and Renvall, M. (2010). Stories of a Public Journalism and the Validity of Citizens' Testimonies. Journalism: Theory, Practice and Criticism, 11 (5): 515-529.

Latu, K. (2015a). PM Pohiva says costs of overseas travel, spending on government vehicles, will be strictly monitored. New Zealand Kaniva Pacific, Auckland, New Zealand, January 14. 
Latu, K. (2015b). Pohiva's meeting with King a "great opportunity," but HM wants political boundaries to be respected. New Zealand Kaniva Pacific, Auckland, New Zealand, January 4.

Latu, K. (2014a). Prime Minister 'Akilisi Pohiva unveils cabinet lineup. New Zealand Kaniva Pacific, Auckland, New Zealand, December 31.

Latu, K. (2014b). PM Pohiva: We have to prove to His Majesty that we can work together to build Tonga. New Zealand Kaniva Pacific, Auckland, New Zealand, December 30.

Latu, K. (2014c). Democrats promise tax cuts, price cuts, curbs on overseas businesses, as they reveal election policies. New Zealand Kaniva Pacific, Auckland, New Zealand, September 15.

Locke, K. (2015). Tonga's democracy champion becomes PM. The Daily Blog, Auckland, New Zealand, January 3.

Matangi Tonga. (2015). PM to trim govt expenses, starting from the top. Matangi Tonga Online, Nuku'alofa, Tonga, January 9.

Matangi Tonga. (2014). People's Reps call for a commoner Prime Minister. Matangi Tonga Online, Nuku'alofa, Tonga, December 3.

Moala, K. (2015). Tonga's PM 'Akilisi Pohiva - long, hazardous road from chief critic to power. Pacific Scoop: Analysis, Auckland University of Technology Pacific Media Centre, Auckland, New Zealand, January 7.

Moala, K. (2014a). The pro-democracy movement rises again. Pacific Politics: Pacific news and analysis brought to you by the Pacific Institute of Public Policy, Pacific Institute of Public Policy, Port Vila, Vanuatu, November 20.

Moala, I. (2014b). Tonga to spark discussions before elections. Dateline Pacific: Radio New Zealand International, Auckland, New Zealand, June 16.

Mohanram, R. (1999). Black Body: Women, Colonialism and Space. New South Wales, Australia: Allen and Unwin.

Naples, N. A. (Ed.) (1998). Community Activism and Feminist Politics: Organizing Across Race, Class, and Gender. London and New York: Routledge.

New Zealand Herald. (2015). Editorial: Tricky road ahead for Tongan PM. The New Zealand Herald, Auckland, New Zealand, January 5. 
Niumeitolu, V. (2010). Tongan American Creation Myth, Spoken Word Poem Performed by Vaimoana Niumeitolu at the University of Utah, Salt Lake City, Utah, United States, February 11.

Pamatatau, R. (2014a). Journal entries on Tonga fieldwork, 24th November to December 1st, Auckland, New Zealand and Nuku'alofa, Tonga, November 24 - December 1.

Pamatatau, R. (2014b). Fieldwork conversations in Tonga, 24 November to December 1st, Nuku'alofa, Tonga, November 24 December 1.

Pamatatau, R. (2012). Chapter 11: From festivals to famine - and the silence in between: A reflection on Pacific Islanders, presentation and re-presentation in media. In Scooped: The politics and power of journalism in New Zealand, edited by M. Hirst, S. Phelan, and V. Rupar. Auckland, New Zealand: Exisle Publishing, Pp. 183-200.

Radio New Zealand. (2014a). Focus on governance first up for Tonga Govt. Radio New Zealand International, Auckland, New Zealand, December 31.

Radio New Zealand. (2014b). Tongan leader names one noble in Cabinet. Radio New Zealand International, Auckland, New Zealand, December 31.

Radio New Zealand. (2014c). Major hurdles for new Tonga PM academic. Radio New Zealand International, Auckland, New Zealand, December 30.

Radio New Zealand. (2014d). Accountability push in Tonga election. Radio New Zealand International, Auckland, New Zealand, November 12.

Radio New Zealand. (2014e). Dumped Tonga MP happy as independent. Radio New Zealand International, Auckland, New Zealand, November 6.

Radio New Zealand. (2014f). More Tongan women to contest poll. Radio New Zealand International, Auckland, New Zealand, October 28.

Radio New Zealand. (2014g). Number of candidates standing in Tonga's 2nd election drops. Radio New Zealand International, Auckland, New Zealand, October 24. 
Radio New Zealand. (2014h). Demo leader in Tonga retains hope despite further election blow. Radio New Zealand International, Auckland, New Zealand, September 3.

Radio New Zealand. (2014i). Two more Demo MPs to go alone in Tonga's elections. Radio New Zealand International, Auckland, New Zealand, September 2.

Said, E. (1991). Chapter 10: Travelling Theory. In The World, The Text and The Critic by E. W. Said. London, United Kingdom: Vintage Books, Pp. 226-247.

Tonga Herald. (2014). Lord Ma'afu: A Representative as Prime Minister is Highly Achievable. The Tonga Herald: We Are The Future, Nuku'alofa, Tonga, December 2.

Tongan Women in Action Collective. (2015). Press Release: “Come up with legislation to change the situation: Prime Minister 'Akilisi Pohiva. Tongan Women in Action Collective, Facebook Group Page, Nuku'alofa, Tonga, January 8.

Tora, I. (2015). PM says code of conduct will be their guide. Tonga Daily News, Nuku'alofa, Tonga, January 6.

Tora, I. (2014). PM Pohiva names Sovaleni as deputy in cabinet lineup. Tonga Daily News, Nuku'alofa, Tonga, December 30.

Turner, G. (2010). Ordinary People and the Media: The Demotic Turn. London, United Kingdom: Sage Publications.

Vaka'uta, K. (2014). Tonga Democrats confident despite losing candidates. Dateline Pacific: Radio New Zealand International, Auckland, New Zealand, September 4.

Wiseman, D. (2014a). Tonga's Democratic Party in Tonga focuses on rule of law. Dateline Pacific: Radio New Zealand International, Auckland, New Zealand, November 12.

Wiseman, D. (2014b). Grassroots focus for Tonga election candidate. Dateline Pacific: Radio New Zealand International, Auckland, New Zealand, July 16.

Wolfgramm, R. (2015). Facebook status for Lisiate T. Wolfgramm, Salt Lake City, Utah, United States, January 8.

United Nations. (1948). The Universal Declaration of Human Rights. United Nations General Assembly, New York, United States, December 10 . 


\section{Photographs}

Photograph 1

Photograph 2

Photograph 3

Photograph 4

Photograph 5
Nuku'alofa, Tonga, by Teena Brown Pulu

Nuku'alofa, Tonga, by Richard Pamatatau

Nuku'alofa, Tonga, by Teena Brown Pulu

Ma'ufanga, Tonga, by Teena Brown Pulu

Haveluloto, Tonga, by Teena Brown Pulu

\section{Endnotes}

1 Who's who in the zoo is Richard Pamatatau's Master of Philosophy thesis title at Auckland University of Technology. Richard's thesis investigates how New Zealand social pages in traditional media, e.g. the weekend pages of The New Zealand Herald newspaper, select, rank, and frame the who's who of public celebrities.

2 See Scott Hamilton's foreword titled 'Teena Pulu Brown rattles Tonga's cage' on his website blog Reading the Maps. Hamilton misspells Richard Pamatatau's surname as Richard Papamatautau and mixes up Teena Brown Pulu's surname as Teena Pulu Brown.

Hamilton, S. (2014). Teena Pulu Brown rattles Tonga's cage. Reading the Maps, New Zealand, December 15.

3 Sefita Hao'uli pointed out in editing comments on a draft of this essay, which he emailed on the morning of Friday January 16th 2015, that although the Democratic Party did not win the most votes by a long short at the Tonga election 2014, party leader Akilisi Pohiva did win his constituency seat - Tongatapu constituency no. 1 - by a clear majority.

4 Sefita Hao'uli's editing comments on 16 January 2014 inquired whether I had read Kalafi Moala's political commentary published on the Pacific Public Policy Institute website in reference to arguing against my claim that Pohiva had fudged media with vague Democratic Party policy outlines. Moala's opinion piece suggests that Pohiva had gestured prior to the Tonga election 2014 that stamping out state corruption was his fundamental political agenda. However, the Democratic Party's policy priorities released to the public in mid-September of 2014 listed cuts in tax and consumer goods, as well as restrictions on overseas businesses moving revenue made in Tonga offshore, as the pressing economic development area the party would take action on if elected to government (Latu, 2014c). 
Moala, K. (2015). Tonga's PM 'Akilisi Pohiva - long, hazardous road from chief critic to power. Pacific Scoop: Analysis, Auckland University of Technology Pacific Media Centre, Auckland, New Zealand, January 7.

Latu, K. (2014c). Democrats promise tax cuts, price cuts, curbs on overseas businesses, as they reveal election policies. New Zealand Kaniva Pacific, Auckland, New Zealand, September 15.

5 Sefita Hao'uli noted in editing comments on 16 January 2015 that Prime Minister Pohiva had stated to Tongan and New Zealand media his desire "to prove to His Majesty [King Tupou VI] that we can work together to build Tonga" (Latu, 2014b). Essentially, this implies that a double-edged political strategy is at work in the current government. First, Pohiva gives the allusion to voters in the Tonga election of 2014 that he has formed a coalition government representative of Democratic Party, independent, and nobles' representatives to demonstrate competency and collaboration in the state bureaucracy to the monarch. Second, an underlying notion of appeasement is detected in Pohiva's sentiments. Placating the monarch by operating a trouble-free bureaucracy could, in theory, afford the Democratic Party political leverage to push for further parliamentary reforms in Tonga's constitution during the Pohiva government's 2014 to 2018 term; i.e. abolishing the nobles' in-house election by allowing registered voters on the Tonga general roll to elect nobles' representatives to parliament every four years.

Latu, K. (2014b). PM Pohiva: We have to prove to His Majesty that we can work together to build Tonga. New Zealand Kaniva Pacific, Auckland, New Zealand, December 30.

6 Flights said in plural, rather than saying "enjoy your flight" in the singular, is a common speech and grammatical error that Native speakers of the Tongan language make when speaking or writing in English. They readily confuse singular and plural, which is thought of by many Tongans who speak English as a first language as a comical FOB [fresh off the boat] mistake that migrant, Native speaking Tongans do.

7 See Brown Pulu, T. (2014a). Who's who in the zoo? Tonga election 2014. Published in Hamilton, S. (2014). Teena Pulu Brown rattles Tonga's cage. Reading the Maps, New Zealand, December 15.

"Back in New Zealand after election week, Ma'afu texted me. Outgoing Minister for Lands and a high-ranking noble re-elected to parliament, I picked a fight with him in Tonga and came off 
second best. His message beckoned me to bury the bush knife and relate.

"If the Nobles support Vaea, [I] am crossing the floor" (Ma'afu, 2014). I nearly died. Read the one-liner dazed: Ma'afu was "crossing the floor?" Is he drunk? I grappled to take in that this noble might actually cross the parliamentary floor to support the nomination from the people's representatives for Tonga's Prime Minister. The noble Ma'afu was doing democracy. Why was it hard for me to accept that? What double standards I had." (Brown Pulu, 2014a).

To be brutally honest, I did not know whether Ma'afu would stand his ground on arguing against his class peers in the nobility that it was not the time in Tonga's political history to put up a nobles' candidate at the prime minister's election on December 29th 2014. But he possessed the fortitude and human spirit to pull it off. Unfolding before the public was the lone noble of Vaini and Tokomololo versus the rest, with his strong-willed avowal that he would cross the floor in the House to vote for the prime ministerial nomination from the people's representatives if the nobles did not withdraw Vaea as their candidate. For this act of bravery and political conviction, Ma'afu won the respect of ordinary Tongan people in the homeland and overseas.

8 See Brown Pulu, T. (2012). Ma'afu's word is in the hills: What is a noble's role in a democratised Tonga? Te Kaharoa: The e-Journal on Indigenous Pacific Issues, 5 (1): 138-208. 